\title{
Impact of PPFM and PGRs on Seed Germination, Stress Tolerant Index and Catalase Activity in Tomato (Solanum lycopersicum L) under Drought
}

\author{
P. Chandrasekaran, R. Sivakumar*, G.K. Nandhitha, M. Vishnuveni, \\ P. Boominathan and M. Senthilkumar
Department of Crop Physiology, Tamil Nadu Agricultural University, Coimbatore - 641003 , India
*Corresponding author

\section{A B S T R A C T}

\begin{tabular}{l} 
Ke y w o r d s \\
Tomato, Drought, \\
PEG, PPFM, \\
Brassinolide, \\
Germination, \\
Stress Tolerant \\
Index, \\
Catalase. \\
Article Info \\
\hline $\begin{array}{l}\text { Accepted: } \\
\text { 04 May } 2017 \\
\text { Available Online: } \\
\text { 10 June } 2017\end{array}$ \\
\hline
\end{tabular}

Drought is major abiotic stress around the world which posturing great challenges to the germination, growth and production of crops. Early crop growth stages like germination and seedling growth are very critical under drought. Seed treatment technologies are required to enhance the germination and stress tolerant index of the seedlings under drought condition. The investigation was aimed to carry out to assess the impact of PPFM (Pink Pigmented Facultative Methylotroph) and PGRs on alleviating the drought stress effects in tomato in early growth stage. Laboratory experiment was carried out in tomato variety PKM 1 and seeds soaking with different plant growth regulators like brassinolide $(1 \mathrm{ppm})$, salicylic acid (100 ppm), benzyl amino purine $(100 \mathrm{ppm})$ and gibberellic acid (10 ppm) and PPFM (1\%), PPFM (2\%) and PPFM (3\%) under drought condition created by PEG 6000. The study indicated that the PPFM and PGRs could be effectively used for improving seed germination and its associated traits under drought. Among the PGRs and different concentrations of PPFM used, PPFM (2\%) was found to superior in improving germination associated traits and stress tolerant index. The anti-oxidant enzyme catalase activity was enhanced by PPFM (2\%) and brassinolide (1 ppm) treatments which has the ability to protect the plant under abiotic stress.

\section{Introduction}

Water plays a vital role in agriculture and major factor decides the production of crops. In every part of the world, it is the limiting factor for agricultural crops in general and for vegetables in particular. Drought stress affects agriculture productivity and yield. It is an important factor, which harms more than 50 per cent of crop yield worldwide (Wang et al., 2003). Harris et al., (2002) reported that the first and foremost effect of drought is impaired germination and poor stand establishment. Seed vigour index is also an important component that can influence crop plant density and yield (Siddique and Wright, 2004).

Plant growth regulators (PGRs) have been found to play a key role in the integration of the responses expressed by plants under stress conditions (Amzallag et al., 1990). Methylobacterium species are a group of bacteria known as pink-pigmented facultative methylotrophs, or PPFMs (Green and Bousfield, 1983). Holland (1997) reported 
that PPFMs could be used as in seed coatings designed to enhance germination and vigour index. The advantage for PPFM bacteria is a rich supply of plant hormones, as most of the metabolic products of the methanol released by plants are lost from leaves during leaf expansion, which is catalyzed by pectin methylesterase (Dourado et al., 2015).

Brassino steroids are endogenous plant growth promoting hormones that act on plant development and affect numerous physiological processes at low concentrations (Zullo and Adam, 2002), and senescence is a developmentally regulated and genetically programmed process that may be mediated by brassinosteroids (Vardhini and Rao, 2002). Cytokinins are special chemical messengers in plants that play pivotal role in managing plant cell life cycle and delaying senescence. Werner et al., (2010) reported that the cytokinin modifies many physiological activities induced by drought stress. Akter et al., (2014) reported that the exogenous application of GA3 could effectively alleviate the adverse effects of drought stress and eventually provide maximum growth and yield in maize. Salicylic acid (SA) belongs to phenolic compound and is an endogenous growth regulator which participates in regulation of physiological processes in plants such as seed germination and yield (Khan et al., 2003).

Based on information available on drought mitigation, the present investigation was carried out to evaluate the effect of plant growth regulators and PPFM to mitigate the effect of drought in tomato PKM 1. An attempt was made to alleviate the drought effect by seed soaking method of plant growth regulators and PPFM.

\section{Materials and Methods}

The experiment was carried out in the petridishes under laboratory condition. The seeds were allowed to germinate in the petridishes. The drought was created by using PEG 6000 (-0.15 MPa). The treatment like absolute control (Without drought), Control ($0.15 \mathrm{MPa})$, PPFM (1\%), PPFM (2\%), PPFM (3\%), Brassinolide (1 ppm), Salicylic acid (100 ppm), BAP (100 ppm) and GA 3 (10 ppm) were used for this experiment.

Seeds were soaked in above mentioned plant growth regulators and PPFM solutions for 4 hours. After, the seeds were dried under shade for 4 hours. Later the treated seeds were placed on germination paper in each petridish separately, untreated seeds in control and absolute control. The germination paper was moistened regular interval with $-0.15 \mathrm{MPa}$ PEG 6000 solution for drought induction and distilled water for absolute control. The petridishes were kept in laboratory under room temperature.

The germination was recorded at every 24 hours interval up to 15 days and finally germination was recorded on the 15th day and seed germination percentage was calculated by using the following formula and expressed as per cent. Germination percentage = (Number of germinated seeds / Number of seeds kept for germination) x 100 .

On 15th day, seedlings from each replication were carefully removed at random. Length of shoot was measured from the collar region to the tip of the longest leaf and expressed as $\mathrm{cm}$. Root length of the seedling was measured from the base of the stem to the tip of the longest root and expressed as $\mathrm{cm}$. The vigour index of the seedlings was calculated by using the following formula proposed by AbdulBaki and Anderson (1973). Vigour Index = (Shoot length + Root length) $x$ Germination percentage. Stress tolerance index (STI) was calculated using the following formula proposed by Dhopte and Livera (1989) and expressed as per cent. STI = (Vigour index of the treated seedling / Vigour index of the 
absolute control seedling) x 100. Catalase activity was determined by titration method using potassium permanganate (Gopalachari, 1963) and expressed as $\mu \mathrm{g} \mathrm{H}_{2} \mathrm{O}_{2} \mathrm{~g}^{-1} \mathrm{~min}^{-1}$. Total phenolics content was estimated by adopting the protocol given by Malik and Singh (1980). The data on various parameters were analyzed statistically as per the procedure suggested by Gomez and Gomez (1984).

\section{Results and Discussion}

Seed germination is one of the most crucial and decisive phases in the growth cycle of plant species since it determines plant establishment and final yield of the crops. Poor germination and seedling establishment are resulted in drought stress.

In the present study, the germination percentage was reduced up to 39.40 per cent under drought created by PEG 6000. PEG concentration inhibited the germination of the control plants and caused them to record low germination percentage. The higher germination percentage of the absolute control was due to their ability to absorb water in normal condition. Previous studies investigated PEG treatments can lead to a reduction in germination percentage by decreasing the water potential gradient between seeds and their surrounding media (Dodd and Donavan, 1999).

This is in agreement with present investigation. Low availability of soil moisture decreases seed germination and seedling growth (Gamze et al., 2005). Therefore, any treatment which could be used to improve seed germination and subsequent seedling establishment under drought conditions would be highly desirable. Presowing seed treatments have been shown to enhance establishment in germination.
Impact of PPFM and PGRs on seed germination and seedling characters

Among the treatments, PPFM (2\%) showed higher germination percentage $(73.53 \%)$ when compared to control (55\%) followed by salicylic acid (71\%). Presoaking with PPFM (2\%) treatment enhance the germination up to 33.69 per cent when compared to control (Table 1). This may be due to PPFMs are providing such a huge amount of compounds to enhance the seed germination. PPFM bacteria stimulate plant growth (Basile et al., 1969) presumably because they produce the plant growth regulators (Freyermuth et al., 1996) and vitamin B12 (Basile et al., 1985). This increment may have been due to the Gibberellin (GA3) improves the synthesis and secretion of hydrolytic enzymes from aleurone cells. These enzymes then mobilize the endosperm storage reserves that are fuel for germination and growth (Cirac et al., 2004).

Among the treatments, the highest mean shoot length was recorded in absolute control $(6.31 \mathrm{~cm})$ and the minimum mean shoot length was produced in control $(3.09 \mathrm{~cm})$. Among the PGRs and PPFM used, PPFM (2\%) recorded longest shoot length of $5.67 \mathrm{~cm}$, followed by gibberellic acid $(5.40 \mathrm{~cm})$. The shoot length was decreased up to 51.03 per cent under drought stress. Shoot length may not be much affected by the drought situation at germination stage. The result was described by Kulkarni and Deshpande (2007) in the study on tomato genotypes.

Seed soaking with PPFM (2\%) enhances the shoot length $(5.67 \mathrm{~cm})$ followed by gibberellic acid $(5.40 \mathrm{~cm})$ and salicylic acid $(4.91 \mathrm{~cm})$. The similar result by salicylic acid induce shoot growth of barley (Pancheva, 1996) and wheat (Shakirova, 2007), root length of soya bean (AlHakimi, 2008) under drought condition. 
Table.1 Effect of PPFM and plant growth regulators on seed germination and seedling characters of tomato (PKM 1) under drought

\begin{tabular}{|c|c|c|c|}
\hline Treatments & $\begin{array}{c}\text { Germination } \\
\text { Percentage }(\%)\end{array}$ & Shoot length $(\mathrm{cm})$ & Root length (cm) \\
\hline $\mathrm{T}_{1}$ : Absolute control & 90.76 & 6.31 & 4.53 \\
\hline $\mathrm{T}_{2}$ : Control & 55.00 & 3.09 & 1.23 \\
\hline $\mathrm{T}_{3}:$ PPFM (1\%) & 66.90 & 4.85 & 2.38 \\
\hline $\mathrm{T}_{4}:$ PPFM $(2 \%)$ & 73.53 & 5.67 & 3.72 \\
\hline $\mathrm{T}_{5}:$ PPFM (3\%) & 69.80 & 3.45 & 2.35 \\
\hline $\mathrm{T}_{6}$ : Brassinolide (1 ppm) & 70.97 & 4.89 & 2.81 \\
\hline $\mathrm{T}_{7}:$ Salicylic acid (100 ppm) & 71.00 & 4.91 & 2.86 \\
\hline $\mathrm{T}_{8}: \mathrm{BAP}(100 \mathrm{ppm})$ & 69.30 & 4.23 & 2.45 \\
\hline $\mathrm{T}_{9}: \mathrm{GA}_{3}(10 \mathrm{ppm})$ & 68.51 & 5.40 & 3.61 \\
\hline SE (d) & 1.68 & 0.10 & 0.04 \\
\hline $\mathrm{CD}(\mathrm{P}=\mathbf{0 . 0 5})$ & 3.52 & 0.22 & 0.09 \\
\hline
\end{tabular}


Table.2 Effect of PPFM and plant growth regulators on vigour index and stress tolerance index (\%) of tomato under drought

\begin{tabular}{|c|c|c|}
\hline Treatments & Vigour Index & Stress tolerance index $(\%)$ \\
\hline $\mathrm{T}_{1}$ : Absolute control & 983.84 & - \\
\hline $\mathrm{T}_{2}:$ Control & 237.60 & 24.15 \\
\hline $\mathrm{T}_{3}:$ PPFM (1\%) & 483.69 & 49.16 \\
\hline $\mathrm{T}_{4}: \mathrm{PPFM}(2 \%)$ & 690.45 & 70.18 \\
\hline $\mathrm{T}_{5}: \mathrm{PPFM}(3 \%)$ & 404.84 & 41.15 \\
\hline $\mathrm{T}_{6}:$ Brassinolide $(1 \mathrm{ppm})$ & 546.47 & 55.54 \\
\hline $\mathrm{T}_{7}:$ Salicylic acid (100 ppm) & 551.67 & 56.07 \\
\hline $\mathrm{T}_{8}: \mathrm{BAP}(100 \mathrm{ppm})$ & 617.28 & 47.05 \\
\hline $\mathrm{T}_{9}: \mathrm{GA}_{3}(10 \mathrm{ppm})$ & 725.40 & 62.74 \\
\hline SE (d) & 13.27 & 2.63 \\
\hline $\mathrm{CD}(\mathrm{P}=0.05)$ & 27.89 & 5.54 \\
\hline
\end{tabular}


Table.3 Effect of PPFM and plant growth regulators on catalase activity and total phenols of tomato under drought

\begin{tabular}{|c|c|c|}
\hline Treatments & $\begin{array}{c}\text { Catalase activity } \\
\left(\mu \mathrm{g} \text { of } \mathrm{H}_{2} \mathrm{O}_{2} \mathrm{~g}^{-1} \mathrm{~min}^{-1}\right)\end{array}$ & $\begin{array}{c}\text { Total phenols } \\
\left(\mathrm{mg} \mathrm{g}^{-1}\right)\end{array}$ \\
\hline $\mathrm{T}_{1}$ : Absolute control & 6.89 & 3.54 \\
\hline $\mathrm{T}_{2}$ : Control & 5.64 & 4.20 \\
\hline $\mathrm{T}_{3}:$ PPFM (1\%) & 3.54 & 4.54 \\
\hline $\mathrm{T}_{4}: \mathrm{PPFM}(2 \%)$ & 2.96 & 4.76 \\
\hline $\mathrm{T}_{5}:$ PPFM (3\%) & 3.85 & 4.51 \\
\hline $\mathrm{T}_{6}$ : Brassinolide (1 ppm) & 3.12 & 5.09 \\
\hline $\mathrm{T}_{7}:$ Salicylic acid (100 ppm) & 3.37 & 4.24 \\
\hline $\mathrm{T}_{8}: \mathrm{BAP}(100 \mathrm{ppm})$ & 3.65 & 4.33 \\
\hline $\mathrm{T}_{9}: \mathrm{GA}_{3}(10 \mathrm{ppm})$ & 3.91 & 3.95 \\
\hline SE (d) & 0.08 & 0.07 \\
\hline $\mathrm{CD}(\mathrm{P}=\mathbf{0 . 0 5})$ & 0.18 & 0.16 \\
\hline
\end{tabular}


Drought stress decreases 72.84 per cent of root length. Changes in growth during initial stages due to drought would therefore depend on differences in translocation of assimilates from the seed and later on other assimilatory process. Long roots may help the drought tolerant to extract water from the deep soil. Among the treatments, PPFM (2\%) showed higher root length $(3.72 \mathrm{~cm})$ while compared to control followed by gibberellic acid (3.61 $\mathrm{cm}$ and salicylic acid (2.86). This increment might due to, methylobacterium are capable to grow on carbon compounds such as methanol and generate plant growth regulators such as auxin and cytokinin (Ivanova et al., 2000) which induce cell division and cell elongation.

\section{Impact of PPFM and PGRs on vigour index}

Vigour index is the product of germination percentage and seedling length. The vigour index was found highest in absolute control (983.84) and the control showed least value of 237.60 (Table 2). Among the treatments, PPFM (2\%) recorded highest value of 690.45 and followed by gibberellic acid (617.28) and salicylic acid (551.67). Simultaneously, PPFM (3\%) marked on the lowest vigour index of 404.84 and followed by BAP (462.92). Seed vigour index is an important component that can influence crop plant density and yield (Siddique and Wright, 2004). Copeland and McDonald (1995) reported that vigour of seedlings relates with their ability upon germination to grow rapidly and well. It is suggested that speed and uniformity of emergence are important parameters of seed quality. Holland (1997) reported that PPFMs could be used as seed coatings designed to enhance germ inability, vigour of seeds. Similar result was found by Madhaiyan et al., (2004) who reported that PPFM inoculation has resulted in increased seedling vigour, dry matter production and yield. Patel and Mankad (2014) reported that the gibberellic acid increased the vigour index of Tithonia rotundifolia seedling due to enhanced seed germination. Afzal et al., (2005) reported that seed treatment with salicylic acid increases the vigour index in pea seedlings.

\section{Impact of PPFM and PGRs on Stress Tolerant Index}

The stress tolerance index was worked out based on the vigour index of the seedling as the ratio between the values under stress treatment to absolute control (unstressed). The data indicated that, stress tolerance index of control seeds was lower than the seeds treated with PGRs and PPFM. The mean percentage of stress tolerant index of control was 24.15 per cent. Among the treatments given, PPFM (2\%) showed significantly premier mean value of 70.18 per cent followed by gibberellic acid (62.74\%), salicylic acid $(56.07 \%)$ and brassinolide (55.54\%). PPFM (3\%) noticed in least mean value of 41.15 per cent (Table 2). Pinkpigmented facultative methylotrophic (PPFM) bacteria are predominant and explored largely for their ability to release plant-growth regulation molecules (Dourado et al., 2015) and thereby increasing the tolerant capacity. Cytokinin concentrations were significantly increased by PPFM proved that the versatility of Methylobacterium as a plant-growth promoting bacteria could be better exploited (Jeounghyun et al., 2006).

\section{Impact of PPFM and PGRs on catalase activity}

Catalase (CAT) is an important and most powerful antioxidant enzyme under abiotic stress condition to nullify the effect of $\mathrm{H}_{2} \mathrm{O}_{2}$ and protects the plants under stress condition. 
This enzyme is generally regarded as $\mathrm{H}_{2} \mathrm{O}_{2}$ scavenger involved in the reduction of damage by oxidation function (Reddy et al., 2004). The seedlings in absolute control (6.89 $\mu \mathrm{g} \mathrm{H}_{2} \mathrm{O}_{2} \mathrm{~g}^{-1} \mathrm{~min}^{-1}$ ) registered lower enzyme activity than control $\left(5.64 \mu \mathrm{g} \mathrm{H}_{2} \mathrm{O}_{2} \mathrm{~g}^{-1} \mathrm{~min}^{-1}\right)$. Hence, it was showed that the catalase activity increased under stress condition. PPFM (2\%) was noticed highest catalase activity of $2.96 \mu \mathrm{g} \mathrm{H}_{2} \mathrm{O}_{2} \mathrm{~g}^{-1} \mathrm{~min}^{-1}$ followed by brassinolide (3.12 $\mu \mathrm{g} \mathrm{H} \mathrm{H}_{2} \mathrm{O}_{2} \mathrm{~g}^{-1} \mathrm{~min}^{-1}$ ) and lowest was registered in gibberellic acid (3.91 $\mu \mathrm{g} \mathrm{H}_{2} \mathrm{O}_{2} \mathrm{~g}^{-1} \mathrm{~min}^{-1}$ ) followed by $3.85 \mu \mathrm{g} \mathrm{H}_{2} \mathrm{O}_{2}$ $\mathrm{g}^{-1} \min ^{-1}$ of PPFM (3\%) (Table 3). The catalase activity increased up to 18.14 per cent under drought stress when compared to absolute control. Increment of catalase activity by the PGRs used is important role in plant to protect against ROS. It is possible that salicylic acid stimulate the germination of seed via GA biosynthesis and act as thermogene inducers (Shah, 2003).

\section{Impact of PPFM and PGRs on total phenolics}

The minimum value of total phenols observed in absolute control (3.54 mg g-1) and maximum value $\left(4.20 \mathrm{mg} \mathrm{g}^{-1}\right)$ was recorded in control seedlings. Brassinolide was recorded in highest total phenols (5.09 $\mathrm{mg} \mathrm{g}^{-1}$ ) followed by PPFM (2\%) treatment $(4.76 \mathrm{mg}$ $\mathrm{g}^{-1}$ ) (Table 3). Total phenols are secondary metabolic compounds which play a key role in biotic and abiotic stress tolerance. In the present study, the total phenols increased up to 19.05 per cent in control compared to the absolute control. Petkovsek et al., (2009) showed total phenolic content of leaves can be a good tool for distinguishing tolerant capacity of crop plant under biotic and abiotic stress. However, gibberellic acid decreased total phenols up to 5.95 percent. Similar findings observed by Mozetic et al., (2004), total phenols level that act as the antioxidants of reactive oxygen species generated under stress influence and reported the single phenolics content decrease.

In conclusion, current year the agricultural production has been declined due to intense shortage of water which creates historical drought. Of the various management practices available, mitigation through PGRs and bioproducts like PPFM are promising to enhance seed germination, Stress Tolerant Index and catalase activity ultimately further growth and yield. Therefore, these results have practical field application in terms of enhancing seed germination under drought especially PPFM. Further studies would be required to identify the alteration in gene expression in PPFM treated seed and plant.

\section{References}

Abdul-Baki, A. and Anderson, J. D. 1973. Vigor determination in Soybean seed by multiple criteria. Crop Sci. 13: 630-633.

Afzal, I., Basra, S.M.A. Ahmad N. and Farooq, M. 2005. Optimization of hormonal priming techniques for alleviation of salinity stress in wheat (Triticum aestivum L.). Cad. dePes. Serie Biol. 17(1): 95-109.

Akter, N., Rafiqul Islam, M. Abdul Karim, M. and Hossain, T. 2014. Alleviation of Drought Stress in Maize by Exogenous Application of Gibberellic Acid and Cytokinin. J. Crop Sci. Biotech. 17 (1): 41-48.

Al Hakimi, A.M.A. 2008. Effect of salicylic acid on biochemical changes in wheat plants under khat leaves residues. Plant, Soil and Environ. 54: 288-293.

Amzallag, G. N., Lerner, H. R. and PoljakoffMayber, A. 1990. Induction of increased salt tolerance in Sorghum bicolor by $\mathrm{NaCl}$ pretreatment. J. Exp. Bot. 41: 29-34.

Basile, D.V., Slade, L.L. and Corpe, W.A. 1969. An association between a bacterium and a liverwort, Scapania nemorosa. Bull. Torr. Bot. Club. 96: 711-714.

Basile, D.V., Basile, M.R. Li, Q.Y. and Corpe, W.A. 1985. Vitamin B12 stimulated 
growth and development of Jungermannia leiantha Grolle and Gymnacolea inflata (Huds.) Dum. (Hepaticae). Bryologist. 88: 77-81.

Cirac, C., Ayan, A. K. and Kevseroglu, K. 2004. The effects of light and some presoaking treatments on germination rate of st. John worth seeds. Pak. J. Biol. Sci. 7: $182-186$.

Copeland, L. O. and M. B. McDonald. 1995. Seed Vigour and Vigour Tests.

In: Principles of seed science and technology (3rd edition). Chapman and Hall, New York. pp. 153-180.

Dhopte, A. M. and Livera, M. M. 1989. Useful Techniques for Plant Scientists, Forum for Plant Physiologists, Murly Printers, Shivnagar, Akola.

Dodd, G. L. and Donavan, L. A. 1999. Water potential and ionic effects on germination and seedling growth of two cold desert shrubs. Am. J. Bot. 86: 1146-1153.

Dourado, M. N., Camargo Neves, A. A., Santos, D. S. and Araujo, W. L. 2015. Biotechnological and agronomic potential of endophytic pink - pigmented methylotrophic Methylobacterium spp. Biomed. Res. Int. 2015:909 - 916.

Fall, R. and Benson, A.A. 1996. Leaf methanol - the simplest natural product from plants. Trends Plant Sci. 1: 296-301.

Freyermuth, S. K., Long, R. L. Mathur, S. Holland, M. A. Holstford, T. P. Stebbins, N. E. Morris R. O. and Polacco, J. C. 1996. Metabolic aspects of plant interaction with commensal methylotrophs. In: Lindstorm M, Tabita R (eds) Microbial growth on $\mathrm{C} 1$ compounds Kluwer Academic Publishers, New York, pp 21-134.

Gamze, O. D., Mehmet, K. and Mehmet, A. 2005. Effects of salt and drought stresses on germination and seedling growth of pea (Pisum sativum L.). Turk. J. Agric. Fores. 29: 237-242.

Gopalachari, N.C. 1963. Changes in the activities of certain oxidizing enzymes during germination and seedling development of Phaseolus mungo and Sorghum. Ind. J. of Exp. Biol. 1: 98-100.

Green, P. N. and Bousfield, I.J. 1983. Emendation of Methylobacterium. Int. J. Syst. Bacteriol. 33: 875-877.

Harris, D., Tripathi, R.S. and Joshi, A. 2002. On-farm seed priming to improve establishment and yield in dry direct seeded rice, In: Pandey, S., M. Mortimer, L. Wade, T.P. Tuong, K. Lopes and B. Hardy (Eds.), Direct Seeding: Research Strategies and Opportunities, pp: 231240. International Rice Research Institute, Manila Philippines.

Holland, M.A. 1997. Occams razor applied to hormonology. Are cytokinins produced by plants? Plant. Physiol. 115: 865-868.

Ivanova, E.G., Dornina, N.V. Shepelyakovskaya, A.O. Laman, A.G. Brovko, F.A. and Trotsenko, Y.A. 2000. Facultative obligate aerobic methylobacteria synthesize cytokenins. Microbiol. 69: 646-651.

Jeounghyun, R. Munusamy, M. Selvaraj, P. Woojong, Y. Pandiyan, I. Kyounga K. Rangasamy, A. Jongchul, Y. Kye Hoon, K. and Tongmin, S. 2006. Plant growth substances produced by Methylobacterium spp. and their effect on tomato (Lycopersicon esculentum L.) and red pepper (Capsicum annuum L.). J. Microbiol. Biotechnol. 16(10): 16221628

Khan, W., Prithviraj, B. and Smit, D.L. 2003. Photosynthetic responses of corn and soybean to foliar application of salicylates. J. Plant Physiol. 160: 485492.

Kulkarni, M. and Deshpande, U. 2007. In vitro screening of tomato genotypes for drought resistance using polyethylene glycol. African J. Biotech. 6: 691-696.

Madhaiyan, M., Poonguzhali, S. Senthilkumar, M. Seshadri, S. Chung, H. Yang, J. Sundaram, S. and SA, T. 2004. Growth promotion and induction of systemic resistance in rice cultivar Co-47 (Oryza sativa L.) by Methylobacterium spp. Bot. Bull. Aca. Sin. 45: 315 -324. 
Malik, E.P. and Singh, M.B. 1980. Plant Enzymology and Hittoenzymology (1st Edn.) Kalyani Publishers: New Delhi; 286.

Mozetic, B., Trebse, P. Simcic, M. and Hribar, J. 2004. Changes of anthocyanins and hydroxycinnamic acids affecting the skin colour during maturation of sweet cherries

Pancheva, T.V., Popova, L.P. and Uzunova, A.M. 1996. Effect of salicylic acid on growth and photosynthesis in barley plants. J. Plant Physiol. 149: 57-63.

Pasalar, A. and Rezaee, B. 2011. Effect of different treatments on dormancy and stimulate germination of henopodium. Fifth national conference on new ideas in agriculture, pp: 4.

Patel, R. G. and Mankad, A. U. 2014. Effect of gibberellins on seed germination of Tithonia rotundifolia Blake. Int. J. Innov. Res. Sci. Eng. Technol. 3 (3): 1068010684.

Petkovsek, M. M., Stampar, F. and Veberic, R. 2009. Seasonal changes in phenolic compounds in the leaves of scab-resistant and susceptible apple cultivars. Can. J. Plant Sci. 89: 745 -753

Reddy, A.R., Chaitanya, K.V. and Vivekanandan, M. 2004. Droughtinduced responses of photosynthesis and antioxidant metabolism in higher plants. J. Plant Physiol. 161: 1189-1202.

Shah, J. 2003. The salicylic acid loop plant defense. Curr. Opin. Plant Biol. 6: 365371.
Shakirova, F.M. 2007. Role of hormonal system in the manifestation of growth promoting and antistress action of salicylic acid. In: Springer, Dordrecht, pp 69-89.

Shudo, K. 1994. Chemistry of phenyl urea cytokinins. In cytokinik: Chemistry, activity and function (Eds) D. V. Mokk and M. C Mok. CRC Press, Boca Raton.pp:35-42.

Siddique, A.B. and Wright, D. 2004. Effects of date of sowing on seed yield, seed germination and vigour of pea and flax. Seed Sci. Technol. 32: 455-472.

Vardhini, B.V. and Rao, S.S.R. 2002. Acceleration of ripening of tomato pericarp discs by brassinosteroids. Phytochem. 16: 843-847.

Wang, W., Vinocur, B. and Altman, A. 2003. Plant responses to drought, salinity and extreme temperatures: towards genetic engineering for stress tolerance. Planta. 218: $1-14$.

Werner, T., Nehnevajova, E. Kollmer, I. Novak, O. Strnad, M. Kramer, U. and Schmulling, T. 2010. Root-Specific reduction of cytokinin causes enhanced root growth, drought tolerance, and leaf mineral enrichment in Arabidopsis and Tobacco. Plant Cell. 22(12): 3905-3920.

Zullo, M.A.T. and Adam, G. 2002. Brassinosteroids phytohormonesstructure, bioactivity and applications. Brazilian J. of Plant Physiol. 14: 143-181.

\section{How to cite this article:}

Chandrasekaran, P., R. Sivakumar, G.K. Nandhitha, M. Vishnuveni, P. Boominathan and Senthilkumar, M. 2017. Impact of PPFM and PGRs on Seed Germination, Stress Tolerant Index and Catalase Activity in Tomato (Solanum lycopersicum L) under Drought. Int.J.Curr.Microbiol.App.Sci. 6(6): 540-549. doi: https://doi.org/10.20546/ijcmas.2017.606.064 